\title{
Ultrastructural observations on some dendroid and graptoloid graptolites and on Mastigograptus
}

\author{
Denis E.B. Bates, Anna Kozłowska, David Loydell, Adam URBanek \& Stephen WAde
}

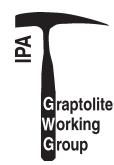

\begin{abstract}
The ultrastructure of the dendroid genera Acanthograptus, Dendrograptus, Desmograptus, Ptilograptus and Dictyonena, the genus Mastigograptus, and the graptoloids Monograptus, Cyrtograptus, Neogothograptus, Paraplectograptus and Sokolovograptus is described. The cortical fibrils of most of the taxa bear a clockwise spiral ornament. There is a striking similarity between the cortical fabric of Dictyonema sp. and the extracellular plies of collagen recognized in extant metazoans. Cortical fibrils may be considered a collagen-like material and the matrix may be compared with a polysaccharide - protein complex. The matrix in Dictyonema and Ptilograptus is formed of regularly spaced interconnecting rods. However, the interconnecting rods are a feature external to the cortical fibrils, and therefore their spacing constitutes only an indirect evidence for the fibrils being formed of a collagen-like material. - Keywords: dendroid, graptoloid, Mastigograptus, ultrastructure, interconnecting rods, spiral fibrils, collagen.
\end{abstract}

BAtes, D.E.B., KoZŁowsKA, A., LOYdELl, D., URBANEK, A. \& WADE, S. 2009. Ultrastructural observations on some dendroid and graptoloid graptolites and on Mastigograptus. Bulletin of Geosciences 84(1), 21-26 (2 figures). Czech Geological Survey, Prague. ISSN 1214-1119. Manuscript received July 20, 2008; accepted in revised form November 18, 2008; published online December 10, 2008; issued March 31, 2009.

Denis Bates, Institute of Geography and Earth Sciences, Aberystwyth University, Aberystwyth, Ceredigion SY23 3DB; deb@aber.ac.uk • Anna Kozłowska, Institute of Paleobiology, Polish Academy of Science, ul. Twarda 51/55, PL-00-818 Warszawa, Poland; akd@twarda.pan.pl • David Loydell, School of Earth and Environmental Sciences, University of Portsmouth, Burnaby Road, Portsmouth PO1 3QL, UK; david.loydell@port.ac.uk • Adam Urbanek, Institute of Paleobiology, Polish Academy of Science, ul. Twarda 51/55, PL-00-818 Warszawa, Poland $\bullet$ Stephen Wade, Institute of Biological, Environmental and Rural Sciences, Aberystwyth University, Aberystwyth, Ceredigion SY23 3DB; scw@aber.ac.uk

The seminal papers of Urbanek \& Towe (1974, 1975), on the ultrastructure of dendroids and graptoloids respectively, have laid the groundwork for our understanding of the structure of the graptolite rhabdosome. However, they were necessarily based on the use of the transmission electron microscope (TEM), and its essentially two-dimensional view; the use of the scanning electron microscope (SEM), with its ability to view in three-dimensions, was in its infancy. Since then, SEM observation has become routine. More recently, the field emission microscope (FEM) development of the SEM has become available, and its extra magnification has begun to yield additional information (Bates 2003). This paper is based on an examination of mainly the material used by Urbanek \& Towe, which has enabled us to compare their TEM results with those from the FEM.

\section{Material}

Acanthograptus? sp. - Erratic boulder 0.327, Middle Ordovician, from Mochty in the valley of the Vistula River some $60 \mathrm{~km}$ N of Warsaw, central Poland, in the collection of the Institute of Paleobiology in Warsaw (Urbanek \& Towe 1974, p. 2): ZPAL G.42/1-2, Stubs 1770B, 1772D.

Dictyonema sp. - Erratic boulder 0.62, Upper Ordovician, from Orłowo near Gdynia, Poland, in the collection of the Institute of Paleobiology in Warsaw (Urbanek \& Towe 1974, p. 2): ZPAL G.42/3-5, Stub 1769B, 1770C, $1774 \mathrm{D}$.

Mastigograptus sp. - Erratic boulder 0.334, Middle Ordovician, $c a 2 \mathrm{~kg}$ in weight, collected at Mochty, in the valley of the Vistula River some $60 \mathrm{~km} \mathrm{~N}$ of Warsaw, central Poland. The boulder is a "grey, fine-grained, dull limestone" (Kozłowski 1960, p. 108), numbered ZPAL G.30/ n in the collection the Institute of Palaeobiology, PAS. This material was illustrated using the SEM by Bates \& Urbanek (2002): ZPAL G.42/6.

Desmograptus micronematodes, Ptilograptus sp. - Racine Dolomite Formation, Wenlock, Silurian, at Thornton quarry, Cook Co., Illinois, USA (Loydell et al. 2002, Saunders et al. in press). Field Museum, University of Chicago, Accession G-7072, Stubs PE60376, PE60771. 
Dendrograptus sp. - The material comes from the topmost Lower Visby Formation, 5.32-5.44 m above the base of the Lusklint Bentonite, Ireviken, Gotland, Sweden. Lower Wenlock: Lower Pterospathodus procerus Biozone of Jeppsson (1997). The material was described using the SEM and TEM by Bates (1997); and by FEM in 2003. Museum of the Department of Geology, Lund University, Sweden. Specimen LO10299.

Cyrtograptus lundgreni, Monograptus flemingii, Paraplectograptus sp., Sokolograptus sp. - Kolka-54 borehole, Cape Kolka, Latvia $\left(57^{\circ} 45^{\prime} \mathrm{N}, 22^{\circ} 35^{\prime} \mathrm{E}\right)$. Material deposited in the Institute of Geology at Tallinn Technical University, Estonia. Cyrtograptus lundgreni Stub GIT-565-2. Monograptus flemingii Stub GIT-565-1. Paraplectograptus sp. Stub GIT-565-4. Sokolovograptus sp. GIT-565-3.

Neogothograptus purus. - Jarosławiec 59, Poland. Lobograptus progenitor and L. scanicus Biozone. Jarosławiec borehole, 59: Stub ZPAL G.42/7.

\section{Ultrastructure: Fusellum}

Fusellar fabric. - Fusellar fabric appears to be fairly uniform in all of the taxa examined, being an irregular meshwork of fibrils (Fig. 1A, E). Fibril diameter ranges from $20 \mathrm{~nm}$ to $70 \mathrm{~nm}$, with a tendency to increase in diameter towards the bounding sheet of a fusellus. Clockwise spiral striae appear to be present in Acanthograptus (Fig. 1A). There is also some indication in Desmograptus that the fibrils have clockwise spiral striae (Saunders et al. in press), similar to those of cortical fibrils. If so, then it is possible that all graptolite fibrils - both those of the fusellum and those of the cortex - have spiral striae.

Sheet fabric. - Sheet fabric (of both the fusellum and cortex) is formed of a granular or structureless material, which appears as a dense black layer in TEM sections (e.g., Urbanek \& Towe 1974, pl. 11). FEM examination has revealed little more than can be observed under the SEM. The internal sheet fabric in Acanthograptus (Fig. 1B) is covered by sparse randomly orientated fibrils.

Cyrtograptus has a pitted sheet fabric (Fig. 2D), which appears to be unique to this genus. It was illustrated by Crowther (1981, pl. 19, fig. 6), and Crowther \& Rickards (1977, pl. 12, figs 3-5).

\section{Ultrastructure: Cortex}

The cortex in all of the genera is made up of individual cortical units, probably forming bandages, although clear parallel-sided bandages have not been seen in all of the taxa examined. Each unit is composed of parallel cortical fibrils, running the length of a unit and forming a cortical fabric, within a matrix, or interspersed with transverse interconnecting rods, and a sheet fabric forming an outer surface. In Dendrograptus the matrix is a granular groundmass between the cortical fibrils, containing vesicles (Fig. 1G). In the retiolitids there is also a dense groundmass, which can bear the imprint of the cortical fibrils (Fig. 2E).

Cortical fibrils. - Cortical fibrils form the most important component of cortical units, and clearly confer tensile strength to each unit. The fibrils vary in thickness in the different taxa: from $80 \mathrm{~nm}$ in Acanthograptus (Fig. 1C) to 170-180 nm in Mastigograptus (Fig. 2B) and Dictyonema (Fig. 1D, E), and $400 \mathrm{~nm}$ in Dendrograptus (Fig. 1G).

The cortical fibrils in most taxa have an ornament of striae which spiral clockwise, as in the Gotland Dendrograptus described by Bates (2003), and illustrated here (Fig. 1G). In Dictyonema (Fig. 1E, F), although the fibrils are much thinner (and of two different diameters), the spacing of the spiral striae is very similar.

Acanthograptus has similar, though less clear, clockwise spiralling striae, with a pattern of transverse ridges superimposed on them (Fig. 1B, C). These transverse ridges are spaced at about 9 per $100 \mathrm{~nm}$. Similar ridges are present in Dictyonema (Fig. 1E). Spiral striae have not been observed in Ptilograptus sp. (Fig. 2A). The spiral angle is about $10^{\circ}$ in all of the genera except for Desmograptus, in which it is $20^{\circ}$.

The cortical fibrils in the retiolitids also spiral clockwise, as shown in Paraplectograptus sp. (Fig. 2F). However, they are embedded in a dense and fine-grained groundmass, which can bear the imprint of the fibrils (Sokolovograptus, Fig. 2E; Neogothograptus, Fig. 2G). In these the impression spirals anticlockwise.

Interconnecting rods. - The smaller fibrils which run perpendicular to the cortical fibrils of the cortex were first illustrated and described by Urbanek \& Towe (1974, p. 7) as interconnecting rods. They have some similarities with the

Figure 1. A-C-Acanthograptus sp., erratic boulder, Mochty, Poland. A - ZPAL G.42/1. Fusellar fibrils with spiral striae. B - ZPAL G.42/2. Surface sheet fabric, with vesicles, cortical fibrils and sheet fabric of an inner cortical unit. C-close-up of B, with transverse ridges superimposed on the spiralling striae. - D-F - Dictyonema sp., erratic boulder, Orłowo, Poland. D - ZPAL G.42/3. Section through cortical unit with cortical fibrils and interconnecting rods; base of unit on the left, sheet fabric of surface with vesicles on the right. E-ZPAL G.42/4. Cortical fabric regularly spaced interconnecting rods. Arrows point to transverse ridges on the spiralling striae. F - ZPAL G.42/5. Cortical fibrils with spiral striae. • G - Dendrograptus sp., LO10299, Ireviken, Gotland. Cortical fibrils with spiral striae, and concentric fibrils, in a granular groundmass. $\bullet \mathrm{H}-$ Desmograptus micronematodes (Spencer, 1884 ), Thornton, Illinois, USA. Field Museum, Chicago G-7072, PE60376. Cortical fibrils with spiral striae, linked by irregularly spaced interconnecting rods. 

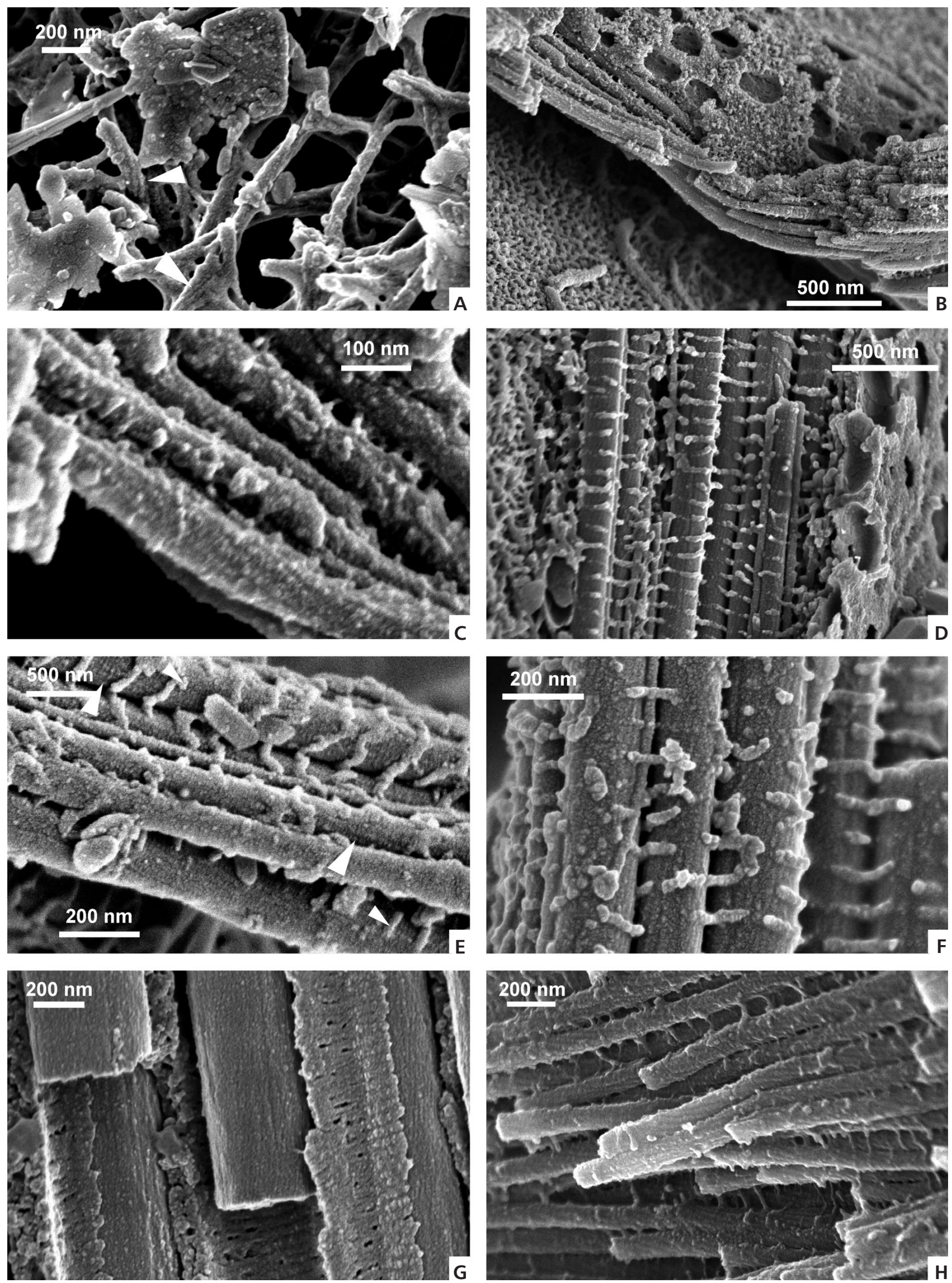
concentric fibrils described by Bates (2003, fig. 1.4) in Dendrograptus (Fig. 1G). These latter, however, are closely packed and appear to spiral around the cortical fibrils.

Interconnecting rods are best developed in Dictyonema, where they are $c a 27 \mathrm{~nm}$ in diameter, and are regularly spaced at intervals of $c a 80 \mathrm{~nm}$ (Fig. 1D-F). These fibrils are clearly seen in the TEM pictures of Urbanek \& Towe (1974, e.g., pl. 10, fig. 1). Ptilograptus also has regularly spaced rods (Fig. 2A). They have also been illustrated in Dictyonema rarum by Rickards \& Dumican (1984, figs 2-5). These authors interpreted them as being flanges on the cortical fibrils.

In Desmograptus (Fig. 1H) the interconnecting rods are not as regularly spaced as in Dictyonema sp.

In Mastigograptus (Fig. 2B), Acanthograptus (Fig. 1A, C) and Monograptus flemingii (Fig. 2C) there are only irregular granules of material which appear to be their equivalent. The TEM picture of Acanthograptus illustrated by Urbanek \& Towe (1974, pl. 10, fig. 2) shows these in section as an irregular patchwork.

\section{Discussion}

The examined ultrastructure of the various fabrics comprising the graptolite external skeletal constructions (frequently called 'periderm') is generally uniform. Fusellar fibrils are generally thinner than cortical fibrils, and are randomly orientated. Sheet fabrics are generally granular, with prominent vesicles, although the pitted fabric of $\mathrm{Cyr}$ tograptus appears anomalous. Cortical fibrils have, where the preservation of the material allows it to be observed, a surface ornament of clockwise-spiralling striae.

The spiral striae of cortical fibrils may well indicate an internal structure, which could also spiral. TEM sections of cortical fibrils illustrated by Urbanek \& Towe (1975, pl. 1) in Pristiograptus dubius and Holoretiolites mancki show dense lines within a lucent core: the pattern described by them as virgular fabric. These have also been observed by Dumican \& Rickards (1984): they suggested that there was a spiral rotation of the unit elements.

The material appearing between cortical fibrils is, however, more variable. Regularly spaced interconnecting rods are a striking feature of some dendroids (Dictyonema and Ptilograptus), but have not been observed in graptoloids. Irregularly spaced interconnecting rods do occur in Desmograptus. Scattered granules are found in dendroids (Acanthograptus), Mastigograptus and graptoloids (Monograptus flemingii). Dendrograptus has a unique spiral enwrapping to the cortical fibrils. Retiolitids have a more densely packed, presumably granular, material between the cortical fibrils: capable of taking the impression of the spiral striae (an equally dense material is also found in Dendrograptus). It is probable that this dense groundmass is related to the structure of the retiolitids, in which the lists form cable- or girder-like structures which have both tensile and torsional strength.

The ultrastructure of particularly the cortical fibrils has been compared with that of collagen by a number of authors (Towe \& Urbanek 1972, Urbanek \& Towe 1974, Towe 1980, Crowther 1981, Rickards \& Dumican 1984). Towe \& Urbanek (1972) have pointed out a striking similarity between the cortical fabric of Dictyonema sp. and the extracellular plies of collagen recognized in connective tissues of extant metazoans. In the light of these considerations, cortical fibrils may be considered a collagen-like material and the matrix associated with the fibrils may be compared with a polysaccharide - protein complex. The presence and significant role of collagen in graptolite skeletal material may be inferred from the presence of considerable quantities of collagenous material in extracellular constructions of Recent pterobranchs (Armstrong et al. 1984), a group closely related to the ancestors of graptolites. Skeletal material is secreted in pterobranchs and in graptolites in a very similar way (Crowther 1981), and patterns of physical organization of fibrous material in both groups are strikingly similar. Moreover, the similarity of fabrics, in both dendroids, and graptoloids, and in Mastigograptus, suggests that the basic structures were established in a common (early or mid-? Cambrian) most probably a rhabdopleurid-like ancestor of all three groups, and remained as a conservative element throughout their subsequent evolution.

While the collagenous nature of fibrous material in graptolite external constructions is strongly suggested by phylogenetic data and general appearance of the preserved

Figure 2. A - Ptilograptus sp., Thornton, Illinois, USA. Field Museum, Chicago G-7072, PE60771. Cortical fibrils of different diameters, and regularly spaced interconnecting rods. • B - Mastigograptus sp., erratic boulder, Mochty, ZPAL G.42/6, Poland. Cortical fibrils with spiral striae, and irregular granules between. $\cdot \mathrm{C}-$ Monograptus flemingii (Salter, 1852), Kolka-54 borehole, Cape Kolka, Latvia. Institute of Geology at Tallinn University of Technology, GIT-565-1. Cortical fibrils with spiral striae, and irregular granules. • D - Cyrtograptus lundgreni (Tullberg, 1883), Kolka-54 borehole, Cape Kolka, Latvia. Institute of Geology at Tallinn University of Technology, GIT-565-2. Cortical fibrils overlain by pitted sheet fabric. - E - Sokolovograptus sp., Kolka-54 borehole, Cape Kolka, Latvia. Institute of Geology at Tallinn University of Technology, GIT-565-3. Groundmass fabric within list, bearing the impressions of cortical fibrils. The striae on the fibrils spiral clockwise, but their impressions spiral anticlockwise. - F - Paraplectograptus sp., Kolka-54 borehole, Cape Kolka, Latvia. Institute of Geology at Tallinn University of Technology, GIT-565-4. Cortical fibrils within list, with striations spiralling clockwise. $\bullet \mathrm{G}-$ Neogothograptus sp., Jarosławiec 59 , ZPAL G.42/7, Poland. Impressions in groundmass of cortical fibrils within list, with anticlockwise spiral striae. $\bullet \mathrm{H}$ - cartilage of the tibia of modern rabbit. 

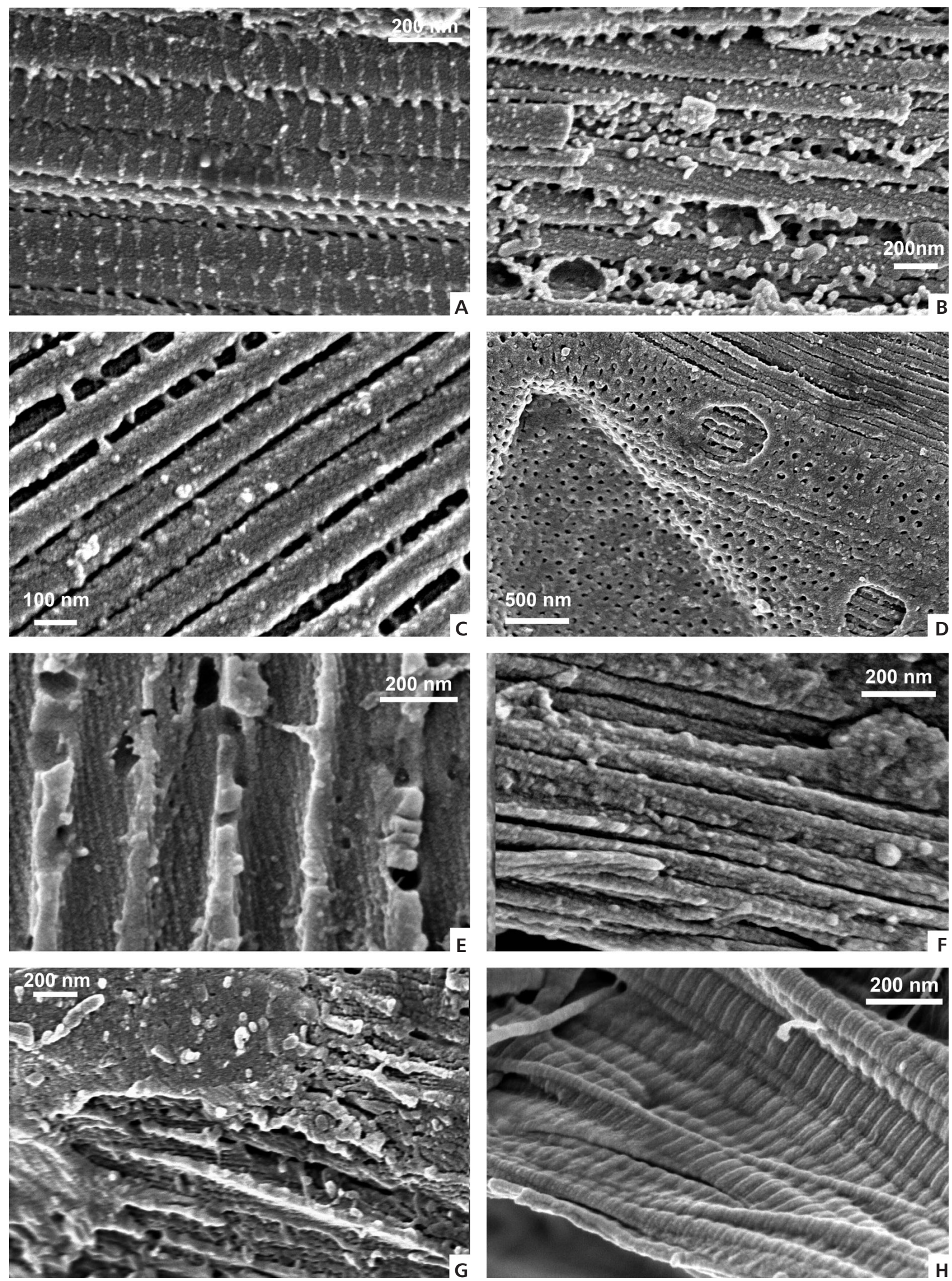
fossil tissue, there is little chemical or physical evidence indicating biochemical composition with any certainty. Attempts at amino acid analysis have produced negative results probably because of a deep diagenetic alteration of the material in question (Briggs et al. 1995, Gupta et al. 2006). As far as the physical features are concerned, the interconnecting rod pattern (flanging of Rickards \& Dumican 1984) has been compared with the $70 \mathrm{~nm}$ repeat pattern in modern collagen (Fig. 2H). However, it is clear from the FEM micrographs that the interconnecting rods are a feature external to the cortical fibrils (and made of distinctly different material with lower electron density), not a flanging of the fibrils as suggested by the above mentioned authors; therefore the spiral striae continue beneath them (Fig. 1F). Hence, the $70 \mathrm{~nm}$ repeat pattern of the interconnecting rods, as seen in Dictyonema sp., cannot represent directly the collagen repeat banding. It may, however, reflect an inner structure of the fibrils - the repeat pattern of the position of certain chemical groups within the collagen fibrils - providing in this way indirect evidence of the banding comparable with modern collagen. In view of the hypothetical nature of this indirect evidence it seems safer to describe the graptolite fibrous material as collagen-like. Moreover, the considerable alteration by diagenesis should be taken into account when comparing fossil and extant organic skeletal structures and necessary caution is required.

A possibility suggested by Towe $(1980$, p. 68$)$, that graptolite periderm was composed of "a fibrous material unknown to date in modern organisms", seems less probable in view of the wide distribution of collagen in the tissues and external structures of Recent hemichordates.

\section{References}

ARMSTRONG, W.G., DiLly, P.N. \& URBANEK, A. 1984. Collagen in the pterobranch coenecium and the problem of graptolite affinities. Lethaia 17, 145-152. DOI 10.1111/j.1502-3931.1984.tb01721.x

BATES, D.E.B. 1997. The ultrastructure of a Silurian dendroid from Gotland (Sweden). Geobios 20, 27-37. DOI 10.1016/S0016-6995(97)80006-X

BATES, D.E.B. 2003. Ultrastructural observations using the field emission microscope and transmission electron microscope on a Silurian dendroid from Gotland (Sweden), 15-19. In ORTEGA, G. \& ACENOlAZA, G.F. (eds) Proceeding of the $7^{\text {th }}$ International Graptolite Conference and Field Meeting of the Subcommission on Silurian Stratigraphy. Consejo Nacional de Investigaciones Cientificas y Técnicas Facultad de
Ciencias Naturales e Instituto Miguel Lillo Universidad Nacional de Tucumán.

BATES, D.E.B. \& URBANEK, A. 2002. The ultrastructure, development and systematic position of Mastigograptus Ruedemann, 1908 (Graptolithina, Hemichordata). Acta Palaeontologica Polonica 47, 445-458.

Briggs, D.E.G, KeAR, A.J., BAss, M., DE LeEUW, J.W. \& RIGBY, S. 1995. Decay and composition of the hemichordate Rhabdopleura: implications for the taphonomy of graptolites. Lethaia 28, 15-23.

DOI 10.1111/j.1502-3931.1995.tb01589.x

CROWTHER, P. 1981. The fine structure of graptolite periderm. Special Papers in Palaeontology 26, 1-119.

Crowther, P. \& RiCKARDS, R.B. 1977. Cortical bandages and the graptolite zooid. Geologica et Palaeontologica 11, 9-46.

GuPTA, N.S., BRIGGS, D.E.G. \& PANCOST, R.D. 2006. Molecular taphonomy of graptolites. Journal of the Geological Society, London 163, 897-900. DOI 10.1144/0016-76492006-070

JEPPSSON, L. 1997. A new latest Telychian, Sheinwoodian and Early Homerian (early Silurian) standard conodont zonation. Transactions of the Royal Society of Edinburgh, Earth Sciences 88, 91-114.

LOydell, D.K., Mullins, G.L., MANNIK, P., Mikulic, D.G. \& KLUESSENDORF, J. 2002. Biostratigraphical dating of the Thornton Fossil Konservat-Lagerstätte, Silurian, Illinois, U.S.A. Geological Journal 7, 269-278. DOI 10.1002/gj.916

RICKARDS, R.B. \& DUMICAN, L.W. 1984. The fibrillar component of the graptolite periderm. Irish Journal of Earth Sciences 6, 175-203.

SALTER, J.W. 1852. Description of some Graptolites from the South of Scotland. Quarterly Journal of the Geological Society of London 8, 388-392, pl. 21.

SAunders, K.M., BATES, D.E.B, Kluessendorf, J., LOYDELL, D.K. \& MIKULIC, D.G. In press. Desmograptus micronematodes, a Silurian dendroid graptolite, and its ultrastructure. Palaeontology.

SPENCER, J.W. 1884. Niagara fossils. Bulletin of the Museum of the University of the State of Missouri 1, 1-61, pls 1-9.

TOWE, K.M. 1980. Preserved organic ultrastructure: an unreliable indicator for Paleozoic amino acid biogeochemistry, 65-74. In HARE, P.E., HoERING, T.C. \& KING, K. JR. (eds) Biogeochemistry of amino acids. Wiley, New York.

TOWE, K.M. \& URBANEK, A. 1973. Collagen-like structures in Ordovician graptolite periderm. Nature 237, 443-445. DOI $10.1038 / 237443 \mathrm{a} 0$

TULLBERG, S.A. 1883. Skånes Graptoliter. II. Graptolitfaunorna i Cardiolaskiffern och Cyrtograptusskiffrarne. Sveriges Geologiska Undersökning, Series C 55, 1-43, pls 1-4.

URBANEK, A. \& TOWE, K.M. 1974. Ultrastructural studies on Graptolites, 1: the periderm and its derivatives in the Dendroidea and in Mastigograptus. Smithsonian Contributions to Paleobiology 20, 1-48. 